\title{
Motor Switch from KIF4 to KIF5 Induces a Selective Reduction in Anterograde Velocity of Fluorescent Cellular Prion Protein in Neurites
}

Hiroki Kato, Kana Nishijima and Naomi Hachiya*

Department of Neurophysiology, Tokyo Medical University, Japan

\begin{abstract}
We previously demonstrated microtubule (MT)-associated kinesin-driven anterograde and dynein-driven retrograde trafficking of cellular prion protein in undifferentiated mouse neuro2a (N2a) cells. The $\mathrm{NH}_{2}$-terminal fragment of the fluorescent cellular prion protein residing inside vesicles (hereafter "vesicular GFP-PrPc") exhibited an anterograde movement towards the direction of the plasma membrane at a speed of $140 \sim \mathrm{nm} / \mathrm{sec}$, which is comparable to the velocity of KIF4-driven movement, and a retrograde movement inwardly at a speed $1,000 \mathrm{~nm} /$ $\mathrm{sec}$, which is comparable to the velocity of dynein-driven movement. We investigated the behavior of movement of vesicular GFP-PrPC in the neurite by first establishing N2a cells that stably expressed GFP-PrPC and treating these with NGF for neurite differentiation, followed by real-time imaging. In neurites, the anterograde kinesin-driven velocity of vesicular GFP-PrPC was selectively reduced to $\sim 50 \mathrm{~nm} / \mathrm{sec}$, which is comparable to the velocity of KIF5, whereas retrograde dynein-driven velocity remained unchanged. Injection of anti-KIF5 antibody into differentiated N2a cells stably expressing GFP-PrPC inhibited the anterograde movement of vesicular PrP in neurites, which exhibited neuriteassociated bulges that lacked $\mathrm{PrP}^{\mathrm{C}}$ signals. These data suggest the involvement of a motor switch from KIF4 to KIF5 in $\operatorname{PrP}^{\mathrm{C}}$ movement in neurites.
\end{abstract}

Keywords: Cellular prion protein $\left(\operatorname{PrP}^{\mathrm{C}}\right)$; Green fluorescent protein (GFP); Microtubules (MTs); Kinesin; KIF4; KIF5; Cell differentiation; Neurites

\section{Introduction}

The prion protein (PrP) consists of two isoforms, a host-encoded cellular isoform $\left(\mathrm{PrP}^{\mathrm{C}}\right)$ and an abnormal protease-resistant pathogenic isoform $\left(\mathrm{PrP}^{\mathrm{sc}}\right)$; the latter is the causative agent of prion diseases. $\mathrm{PrP}^{\mathrm{Pc}}$ stimulates the conversion of $\mathrm{PrP}^{\mathrm{C}}$ into nascent $\mathrm{PrP}^{\mathrm{Sc}}$, and accumulation of $\mathrm{PrP}^{\mathrm{Sc}}$ leads to central nervous system dysfunction and neuronal degeneration [1]. Initial degradation of $\mathrm{PrP}^{\mathrm{C}}$ involves the cleavage of the $\mathrm{NH}_{2}$-terminal fragment to produce a $17-\mathrm{kD} \mathrm{COOH}^{-}$terminal polypeptide, which can be recovered in a Triton X-100 insoluble fraction [2-4]. The $\mathrm{NH}_{2}$-terminal fragment itself functions as a putative targeting element $[5,6]$ and is essential for both movement to the plasma membrane and modulation of endocytosis [7]. $\mathrm{A} \mathrm{NH}_{2}$-terminal GFP-tagged version of $\operatorname{PrP}^{\mathrm{C}}\left(\mathrm{GFP}-\mathrm{PrP}^{\mathrm{C}}\right)$ was found to anchor properly at the cell surface, and its distribution pattern was similar to that of endogenous $\mathrm{PrP}^{\mathrm{C}}$ [8-11] and a $\mathrm{COOH}$-terminal tagged version $\left(\mathrm{PrP}^{\mathrm{C}}-\right.$ GFP) [12].

Knowledge of the physiological role of cellular prion protein is important for the understanding of prion disease; however, despite many efforts, the exact role of cellar prion protein remains unclear. For this reason, we have investigated cellular prion protein by transient transfection of fluorescent $\mathrm{PrP}^{\mathrm{C}}$. We previously demonstrated a microtubule (MT)-associated intracellular localization and movement of the $\mathrm{NH}_{2}$-terminal fragment of fluorescent $\operatorname{PrP}^{\mathrm{C}}$ [13] in mouse neuroblastoma neuro2a (N2a) cells, which are known to be infectable with $\operatorname{PrP}^{\text {sc }}$ [14], and in HpL3-4 cells (a hippocampal cell line established from prnp-ablated mice [15]). We detected the $\mathrm{NH}_{2}$-terminal fragment predominantly in intracellular compartments, while the $\mathrm{COOH}$ terminal fragment was predominantly detected at the cell surface membranes, overlapping with lipid rafts. The full length $\operatorname{PrP}^{\mathrm{C}}$ showed a merged color of both terminals in the Golgi compartments. The $\mathrm{NH}_{2}$-terminal fragment of $\operatorname{PrP}^{\mathrm{C}}$ seems to reside inside vesicles, which may not reflect a distribution within any single specific organelle [13], where integral membrane and linker proteins would be required for interaction with MTs to bridge the luminal and cytoplasmic phases across membranes [16-18]. Accordingly we refer to this fragment hereafter as "vesicular GFP-PrPC."

Following transient transfection into N2a cells, vesicular GFP$\operatorname{PrP}^{\mathrm{C}}$ exhibited an anterograde movement in the direction of the plasma membrane at a speed of kinesin super family KIF4 $(140 \sim \mathrm{nm} /$ sec) and an inward retrograde movement at a speed of dynein $(1,000$ $\mathrm{nm} / \mathrm{sec}$ ), as determined by real-time imaging studies. Kinesin and dynein inhibitors blocked the anterograde and retrograde movements of vesicular GFP-PrP ${ }^{C}$, respectively, and anti-kinesin antibody blocked its anterograde movement, whereas anti-dynein blocked its retrograde movement [19]. These data suggest a kinesin (KIF4)-driven anterograde and dynein-driven retrograde movement of vesicular GFP-PrP ${ }^{C}$; in addition, residues 53-91 and 23-33 were indispensable for interactions with kinesin and dynein, respectively $[13,19]$. These results were obtained using undifferentiated cultured cells, but little is known about the behavior of intracellular $\mathrm{PrP}^{\mathrm{C}}$ in differentiated neuronal cells. We have recently established an N2a cell line that stably expresses GFP-PrP ${ }^{\mathrm{C}}$ and have further examined the intracellular trafficking of vesicular GFP-PrPC in these cells under the differentiated condition. These experiments have identified a significant reduction exclusively in the kinesin-driven anterograde, but not in the dyneindriven retrograde, velocity of vesicular GFP- $\mathrm{PrP}^{\mathrm{C}}$ trafficking in the outgrowing neurites.

*Corresponding author: Naomi Hachiya, Department of Neurophysiology, Tokyo Medical University, Tokyo 160-8402, Japan, Tel: +81-3-3351-6141; Fax: +81-33351-6544; E-mail: naomi@tokyo-med.ac.jp

Received March 15, 2013; Accepted May 27, 2013; Published June 01, 2013

Citation: Kato H, Nishijima K, Hachiya N (2013) Motor Switch from KIF4 to KIF5 Induces a Selective Reduction in Anterograde Velocity of Fluorescent Cellular Prion Protein in Neurites. J Neurol Neurophysiol S11:005. doi:10.4172/2155-9562. S11-005

Copyright: (C) 2013 Kato $\mathrm{H}$, et al. This is an open-access article distributed unde the terms of the Creative Commons Attribution License, which permits unrestricted use, distribution, and reproduction in any medium, provided the original author and source are credited. 


\section{Materials and Methods}

\section{Antibodies and drugs}

Anti-PrP rabbit polyclonal antibody K3 was raised against the PrP peptides (amino acid residues 76-90 in mouse PrP). Anti-tubulin antibody DM1A were purchased from Sigma-Aldrich Japan KK, Tokyo, Japan. Anti-KIF5C antibody was purchased from Abcam plc, Cambridge, UK.

\section{Cell cultures, DNA transfection, and drug treatments}

GFP-PrP was constructed as previously described [13,19]. The resulting plasmid was designated as pcDNA3.1-GFP-PrP. N2a cells were obtained from the American Tissue Culture Collection and grown at $37^{\circ} \mathrm{C}$ in $\mathrm{MEM}$ medium supplemented with $10 \%$ fetal bovine serum. N2a cells were stably transfected with pcDNA3.1-GFP-PrP using a DNA transfection kit (Lipofectamine, Life Technologies, CA, USA). Following stable transfection, cells were selected and maintained with $1 \mathrm{mg} / \mathrm{ml}$ of G418 (Wako Pure Chemical Industries, Osaka, Japan). Before imaging analyses, cells were differentiated for 7 days in the presence of $200 \mathrm{ng} / \mathrm{ml} \mathrm{NGF} \mathrm{(Sigma-Aldrich} \mathrm{Japan} \mathrm{KK,} \mathrm{Tokyo,} \mathrm{Japan).}$

\section{Immunofluorescence microscopy}

Indirect immunofluorescence analyses were performed on cells rinsed with PBS containing $\mathrm{Ca}^{2+}$ and $\mathrm{Mg}^{2+}[\mathrm{PBS}(+)]$ and fixed with $10 \%$ formalin in $70 \%$ PBS (+) for $30 \mathrm{~min}$ at room temperature. After four washes with PBS (-), the fixed cells were incubated in 10\% FBS in PBS (-) for $30 \mathrm{~min}$ at room temperature. Cells were then incubated for $1 \mathrm{~h}$ at room temperature with antibodies at desired concentrations. After four washes with PBS(-), the cells were incubated for $1 \mathrm{~h}$ at room temperature with secondary antibodies, which were diluted 1:200 in PBS. The stained cells were washed four times with PBS(-) and mounted with SlowFade Antifade (Life Technologies, CA, USA). Samples were imaged using the Delta Vision microscope system (Applied Precision, Inc., Issaquah, WA, USA). Out-of-focus light in the visualized images was removed by interactive deconvolution.

\section{Live cell imaging}

Cells were cultured on $3.5 \mathrm{~cm}$ glass-bottom dishes (Matsunami Glass Ind., Ltd., Tokyo, Japan) and imaged using the Delta Vision microscopy system (Applied Precision Inc., Issaquah, WA, USA) equipped with an Olympus IX70 camera (Olympus Imaging Corp., Tokyo, Japan). Fluorescence signals were visualized using a quad beam splitter (Chroma Technology Corp., Rockingham, VT, USA ).

\section{Antibody transfection}

Antibodies were transfected into N2a cells using Chariot (Active Motif, CA, USA) following the manufacturer's protocol. In brief, $2 \times$ $10^{5} \mathrm{~N} 2 \mathrm{a}$ cells were cultured in $3.5 \mathrm{~cm}$ glass-bottom dishes. Chariot (6 $\mu \mathrm{l})$ diluted in DMSO $(94 \mu \mathrm{l})$ was combined with $1.25 \mu \mathrm{g}$ antibodies resuspended in $100 \mu \mathrm{l}$ of PBS(-) and incubated at room temperature for $30 \mathrm{~min}$. The cells were washed twice with $2 \mathrm{ml}$ of PBS(-), and the Chariot-antibody complex was mixed with $400 \mu$ l Opti-MEM I medium (Life Technologies, CA, USA). The cells were incubated at $37^{\circ} \mathrm{C}$ in $5 \% \mathrm{CO}_{2}$ for $2 \mathrm{~h}$ and imaged using the Delta Vision microscopy system.

\section{Results and Discussion}

A cell line that stably expressed GFP-PrP was established by transfecting N2a cells with the plasmid and culturing the transfected cells in the presence of G418 (Figure 1A). The cells that stably expressed
GFP-PrP exhibited the same expression pattern as the cells that showed transient expression (Figure 1B). When we added NGF to the stable expression cell line, the neurites extended and vesicular GFP$\operatorname{PrP}^{\mathrm{C}}$ was localized within the neurite. In contrast, undifferentiated cells contained vesicular GFP- $\mathrm{PrP}^{\mathrm{C}}$ predominantly in intracellular compartments, revealing a dot-like distribution pattern (Figure 1C). Immunofluorescence microscopy observation of GFP-PrP ${ }^{\mathrm{C}}$ along with endogenous $\mathrm{PrP}^{\mathrm{C}}$ with MTs (by anti-PrP polyclonal antibody K3/antitubulin monoclonal antibody DM1A) revealed that $\mathrm{PrP}^{\mathrm{C}}$ was localized on MTs in differentiated (Figures 2E-2H) and undifferentiated-N2a cells (Figures 2A-2D). This immunostaining profile supports our previous proposal that vesicular $\mathrm{PrP}^{\mathrm{C}}$ consists of the $\mathrm{NH}_{2}$-terminal $\operatorname{PrP}^{\mathrm{C}}$ fragment and interacts with the MTs [13].

The intracellular trafficking of vesicular GFP-PrPC was then examined by real-time imaging using NGF-differentiated and stably GFP-PrP expressed N2a cells. As shown in Figure 3, the neurite of the differentiated cells showed a reduction in the velocity of anterograde movement of vesicular GFP-PrP ${ }^{\mathrm{C}}$ toward the plasma membranes (i.e., the speed was $\sim 50 \mathrm{~nm} / \mathrm{sec}$, compared to the velocity of cell body movement of $140 \sim \mathrm{nm} / \mathrm{sec}$ ). In contrast, the retrograde velocity in the neurite remained the same as that in the cell body.

The observed anterograde velocity of vesicular GFP-PrP ${ }^{\mathrm{C}}$ (50 $\mathrm{nm} / \mathrm{s}$ ) was comparable to the speed of KIF5-driven movement in the neurites. Therefore, next we examined the possible involvement of motor protein KIF5 for the anterograde movement of vesicular GFPPrP in the neurite by injecting KIF5 antibody into the cells. As shown in the (Figure 4), liposome injection of anti-KIF5 IgG into the stably expressing and differentiated cells selectively blocked the anterograde movement of vesicular GFP-PrP ${ }^{\mathrm{C}}$ in the neurites. In addition, neuriteassociated bulges with excluded $\mathrm{PrP}^{\mathrm{C}}$ signals were produced (Figures 4 E-L). Cells treated with preimmune IgG showed normal anterograde movement in the neurites and no bulges (Figures $4 \mathrm{~A}-\mathrm{D}$ ).

$\mathrm{PrP}^{\mathrm{C}}$ seems to play an important role in subcellular

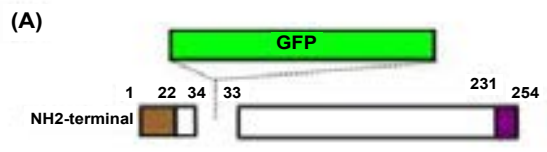

(B)

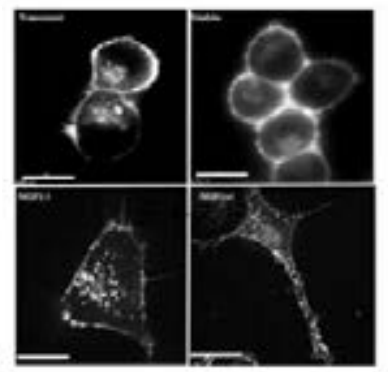

Figure 1: Subcellular distribution profiles of GFP-PrPc

(A) The construction of the plasmid (pcDNA3.1-GFP-PrP). The prion protein has the signal sequence for the secretion at the NH2-terminal (amino acid 1-22) and GPI-anchor signal at the $\mathrm{COOH}$-terminal (amino acid 231-254). GFP insertion is indicated.

(B) Comparison of the subcellular distribution pattern of transiently expressed GFP-PrP (left panel) and stably expressed GFP-PrP (right panel).

(C) Localization of GFP-PrP in stably expressed cells with (right panel) or without (left panel) NGF. Scale bars; $15 \mu \mathrm{m}$. 
compartmentation that occurs distant from the cell body, such as in synapses and neurites. For example, $\mathrm{PrP}^{\mathrm{C}}$ is expressed at high levels in synapses, suggesting an important role in neuronal function that might have vital implications for synaptic homeostasis [20] including synaptic inhibition [21] and copper metabolism [22]. In the neurites, interactions between the neural cell adhesion molecule (NCAM) and $\mathrm{PrP}^{\mathrm{C}}$ promote neurite outgrowth [23]. The establishment of an $\mathrm{N} 2 \mathrm{a}$ cell line that stably expressed GFP-PrP ${ }^{\mathrm{C}}$ allowed us to perform detailed real-time imaging analysis of vesicular GFP-PrPC; in this case, $\mathrm{PrP}^{\mathrm{C}}$ trafficking in live N2a cell neurites. The most significant finding was that the velocity of anterograde kinesin (KIF4)-driven movement was reduced by half and fell within the range of KIF5-driven motility, while the retrograde dynein-driven movement remained unchanged.

Motor proteins, such as the MT-based kinesin superfamily proteins
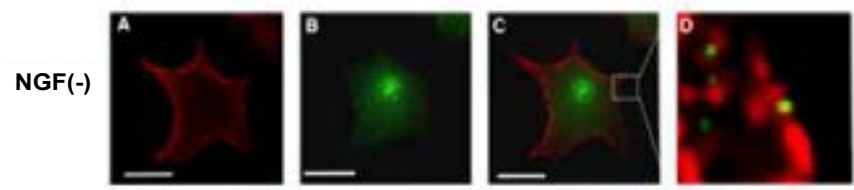

NGF(+)
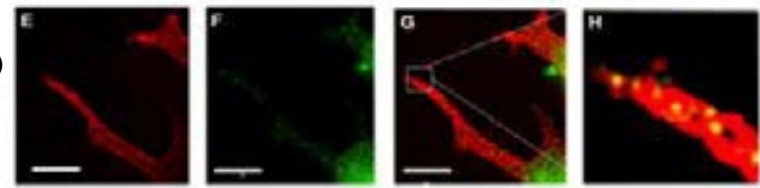

Figure 2: Co-immunostaining of GFP-PrPc and endogenous $\mathrm{PrP}^{\mathrm{C}}$ with microtubules (MTs). Anti-tubulin DM1A (Panels $A$ and E) and anti-PrP K3 (Panels $B$ and $F$ ) detects $\mathrm{PrP}^{\mathrm{C}}$ along with MTs in the presence (Panels $\mathrm{G}-\mathrm{H}$; merged) or absence (Panels C-D; merged) of NGF. Panels D and H shows magnified images. In this experimental condition, anti-PrP polyclonal antibody $\mathrm{K} 3$ recognized endogenous and GFP-fused $\mathrm{PrP}^{\mathrm{C}}$ because it was raised against the PrP peptides (amino acid residues 76-90 in mouse PrP). Scale bars; 15 $\mu \mathrm{m}$

(A)

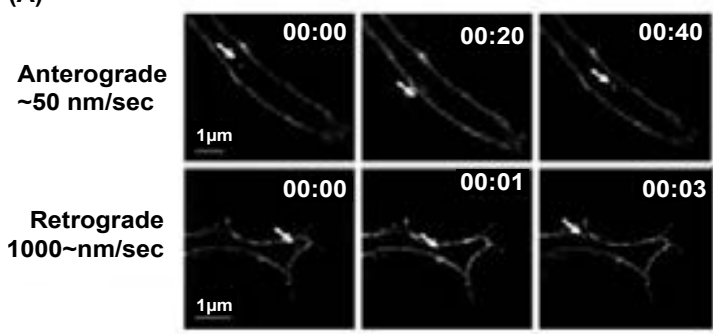

(B)

(C)
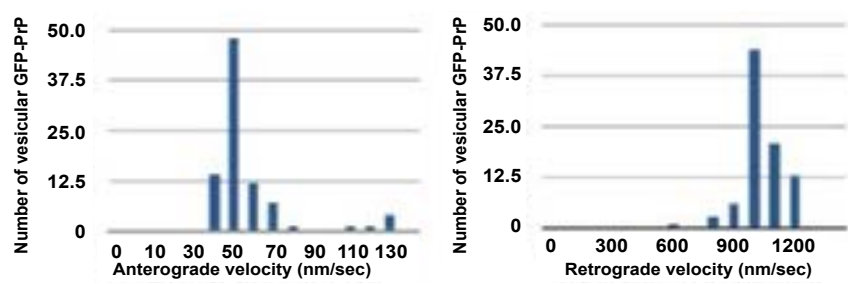

Figure 3: Selective reduction of anterograde velocity of vesicular GFP-PrP in the stable N2a cell neurites. (A) real-time imaging of vesicular GFP-PrP in neurite. The anterograde velocity was consistently reduced but the retrograde velocity remained unchanged. (B and $C$ ) Number of vesicular GFP-PrP in differentiated cells. 88 cells used for the count of the velocity.
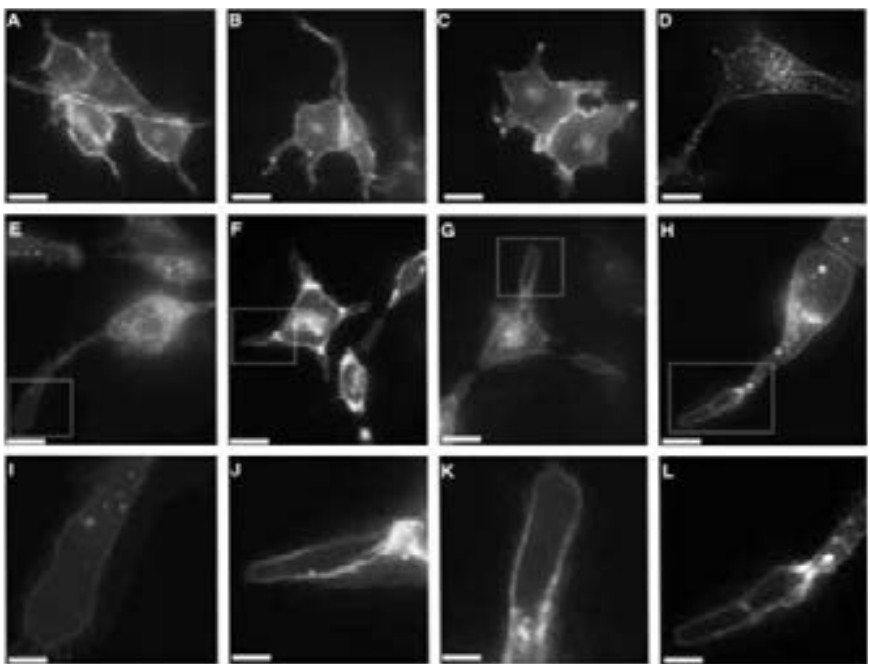

Figure 4: Antibody treatment of vesicular GFP-PrPC. Preimmune IgG injection of NGF differentiated cells stably expressing GFP-PrP (Panels A-D). AntiKIF5C antibody treatment selectively produces neurite-associated bulges that lacked $\mathrm{PrP}^{\mathrm{C}}$ signals (Panels E-H; each magnified images shows on the panels $\mathrm{I}-\mathrm{L})$

(KIFs), are differentiated in the neurites and the cell body, possibly in a cargo-specific manner [24]. Within the kinesin superfamily, KIF4 conveys cargos from the minus to the plus ends of the MTs, a direction that corresponds to anterograde movement, at a speed of $<200 \mathrm{~nm} / \mathrm{sec}$ [25]; this movement is concentrated in the cell body [26]. In contrast, KIF5 conveys cargos (for example containing AMPA-type glutamate receptors [27]) in the neurites at a speed of approximately $50 \mathrm{~nm} / \mathrm{sec}$ [28]. The velocities of plus-end-directed, kinesin-driven movement are thought to vary for a number of reasons [29]. This variation might derive from the complicated environment, where local obstacles such as actin filaments that could impede cargo movement. In addition, the functioning of multiple motors (including dynein) on a given cargo that could load the single kinesin motors, or a reduction in the number of active motors, could lead to lowered cargo movement velocities $[30,31]$.

On the other hand, an alternative view holds that changing the number of motors should not affect the velocity of a vesicle if the motors are kinesins. This view originates from early kinesin gliding assays conducted in buffer, which showed that the velocity is constant over a broad range of kinesin surface densities [32]. Thus, the mechanism by which transported vesicles change their speed remains controversial. Our observations suggest that the motor switch between KIF4 and KIF5 is an underlying mechanism for the velocity change that occurs in a subcellular localization-dependent manner. The precise switching mechanisms of KIF motors, i.e., whether the mode of $\mathrm{PrP}^{\mathrm{C}}$ trafficking observed in the current study is a widespread phenomenon, remains an intriguing question $[25,33]$.

\section{Acknowledgement}

This study was supported by Grants-in-Aid from the Ministry of Health Labor and Welfare and the Ministry of Education, Culture, Sports, Science and Technology, Japan.

\section{References}

1. Prusiner SB (1998) Prions. Proc Natl Acad Sci U S A 95: 13363-13383.

2. Rogers M, Serban D, Gyuris T, Scott M, Torchia T, et al. (1991) Epitope mapping of the Syrian hamster prion protein utilizing chimeric and mutan genes in a vaccinia virus expression system. J Immunol 147: 3568-3574. 
Citation: Kato H, Nishijima K, Hachiya N (2013) Motor Switch from KIF4 to KIF5 Induces a Selective Reduction in Anterograde Velocity of Fluorescent Cellular Prion Protein in Neurites. J Neurol Neurophysiol S11:005. doi:10.4172/2155-9562.S11-005

3. Pan KM, Stahl N, Prusiner SB (1992) Purification and properties of the cellular prion protein from Syrian hamster brain. Protein Sci 1: 1343-1352.

4. Taraboulos A, Scott M, Semenov A, Avrahami D, Laszlo L, et al. (1995) Cholesterol depletion and modification of $\mathrm{COOH}$-terminal targeting sequence of the prion protein inhibit formation of the scrapie isoform. J Cell Biol 129: 121-132.

5. Shyng SL, Heuser JE, Harris DA (1994) A glycolipid-anchored prion protein is endocytosed via clathrin-coated pits. J Cell Biol 125: 1239-1250.

6. Shyng SL, Moulder KL, Lesko A, Harris DA (1995) The N-terminal domain of a glycolipid-anchored prion protein is essential for its endocytosis via clathrincoated pits. J Biol Chem 270: 14793-14800.

7. Nunziante M, Gilch S, Schätzl HM (2003) Essential role of the prion protein N terminus in subcellular trafficking and half-life of cellular prion protein. $\mathrm{J}$ Bio Chem 278: 3726-3734.

8. Lee KS, Magalhães AC, Zanata SM, Brentani RR, Martins VR, et al. (2001) Internalization of mammalian fluorescent cellular prion protein and $\mathrm{N}$-terminal deletion mutants in living cells. J Neurochem 79: 79-87.

9. Magalhães AC, Silva JA, Lee KS, Martins VR, Prado VF, et al. (2002) Endocytic intermediates involved with the intracellular trafficking of a fluorescent cellular prion protein. J Biol Chem 277: 33311-33318.

10. Negro A, Ballarin C, Bertoli A, Massimino ML, Sorgato MC (2001) The metabolism and imaging in live cells of the bovine prion protein in its native form or carrying single amino acid substitutions. Mol Cell Neurosci 17: 521-538.

11. Lorenz H, Windl O, Kretzschmar HA (2002) Cellular phenotyping of secretory and nuclear prion proteins associated with inherited prion diseases. $J$ Biol Chem 277: 8508-8516.

12. Ivanova L, Barmada S, Kummer T, Harris DA (2001) Mutant prion proteins are partially retained in the endoplasmic reticulum. J Biol Chem 276: 42409-42421.

13. Hachiya NS, Watanabe K, Sakasegawa Y, Kaneko K (2004) Microtubulesassociated intracellular localization of the $\mathrm{NH}(2)$-terminal cellular prion protein fragment. Biochem Biophys Res Commun 313: 818-823.

14. Butler DA, Scott MR, Bockman JM, Borchelt DR, Taraboulos A, et al. (1988) Scrapie-infected murine neuroblastoma cells produce protease-resistant prion proteins. J Virol 62: 1558-1564.

15. Kuwahara C, Takeuchi AM, Nishimura T, Haraguchi K, Kubosaki A, et al. (1999) Prions prevent neuronal cell-line death. Nature 400: 225-226.

16. Schliwa M, Woehlke G (2003) Molecular motors. Nature 422: 759-765.

17. Pollard TD (2003) The cytoskeleton, cellular motility and the reductionist agenda. Nature 422: 741-745
18. Howard J, Hyman AA (2003) Dynamics and mechanics of the microtubule plus end. Nature 422: 753-758.

19. Hachiya NS, Watanabe K, Yamada M, Sakasegawa Y, Kaneko K (2004) Anterograde and retrograde intracellular trafficking of fluorescent cellular prion protein. Biochem Biophys Res Commun 315: 802-807.

20. Brown DR (2001) Prion and prejudice: normal protein and the synapse. Trends Neurosci 24: 85-90.

21. Collinge J, Whittington MA, Sidle KC, Smith CJ, Palmer MS, et al. (1994) Prion protein is necessary for normal synaptic function. Nature 370: 295-297.

22. Brown DR, Qin K, Herms JW, Madlung A, Manson J, et al. (1997) The cellular prion protein binds copper in vivo. Nature 390: 684-687.

23. Santuccione A, Sytnyk V, Leshchyns'ka I, Schachner M (2005) Prion protein recruits its neuronal receptor NCAM to lipid rafts to activate p59fyn and to enhance neurite outgrowth. J Cell Biol 169: 341-354.

24. Hirokawa N, Takemura R (2004) Kinesin superfamily proteins and their various functions and dynamics. Exp Cell Res 301: 50-59.

25. Hirokawa N (1998) Kinesin and dynein superfamily proteins and the mechanism of organelle transport. Science 279: 519-526.

26. Peretti D, Peris L, Rosso S, Quiroga S, Cáceres A (2000) Evidence for the involvement of KIF4 in the anterograde transport of L1-containing vesicles. $J$ Cell Biol 149: 141-152.

27. Setou M, Seog DH, Tanaka Y, Kanai Y, Takei Y, et al. (2002) Glutamatereceptor-interacting protein GRIP1 directly steers kinesin to dendrites. Nature 417: 83-87.

28. Nakata T, Hirokawa N (2003) Microtubules provide directional cues for polarized axonal transport through interaction with kinesin motor head. J Cel Biol 162: 1045-1055

29. Mallik R, Gross SP (2004) Molecular motors: strategies to get along. Curr Bio 14: R971-982.

30. Visscher K, Schnitzer MJ, Block SM (1999) Single kinesin molecules studied with a molecular force clamp. Nature 400: 184-189.

31. Svoboda K, Block SM (1994) Force and velocity measured for single kinesin molecules. Cell 77: 773-784.

32. Howard J, Hudspeth AJ, Vale RD (1989) Movement of microtubules by single kinesin molecules. Nature 342: 154-158.

33. Adachi N, Kohara K, Tsumoto T (2005) Difference in trafficking of brain-derived neurotrophic factor between axons and dendrites of cortical neurons, revealed by live-cell imaging. BMC Neurosci 6: 42.
This article was originally published in a special issue, Traumatic Brain Injury: Diagnosis \& Treatment handled by Editor(s). Dr. Douglas Mckay Wallace, University of Miami, USA 